\title{
Work capacity assessment of Nigerian bricklayers
}

\author{
S .O. Ismaila ${ }^{a^{*}}$, K.T. Oriolowo ${ }^{\mathrm{b}}$ and O.G. Akanbi ${ }^{\mathrm{b}}$
}

Department of Mechanical Engineering, University of Agriculture, P.M.B 2240, Abeokuta, Ogun State, Nigeria Department of Industrial \& Production Engineering, University of Ibadan, Oyo State, Nigeria

\begin{tabular}{|c|c|}
\hline A R T I C L E I N F O & A B S T RACT \\
\hline $\begin{array}{l}\text { Article history: } \\
\text { Received March 7, } 2011 \\
\text { Received in Revised form } \\
\text { August, } 25,2011 \\
\text { Accepted } 25 \text { August } 2011 \\
\text { Available online } \\
28 \text { August } 2011 \\
\text { Keywords: } \\
\text { Work capacity } \\
\text { Bricklayers } \\
\text { Energy expenditure } \\
\text { Heart rate } \\
\text { Rest allowance }\end{array}$ & $\begin{array}{l}\text { The main aim of this study is to assess the physical work capacity of bricklayers with focus on } \\
\text { the energy expenditure during work. Eighty Nine bricklayers' working on various sites in } \\
\text { Ibadan and Eruwa towns of Oyo State, Nigeria are used for the study. Correlation and } \\
\text { regression analysis using SPSS } 16.0 \text { Statistical Package was used to determine the relationship } \\
\text { between VO2 given the age and weight of the subjects; \% RHR(Relative Heart Rate) and } \\
\text { working heart rate (HRW) given weight; VO2 and \%RHR given Body Mass Index (BMI). } \\
\text { The results showed that the mean energy expenditure of bricklaying was } 1.51 / \text { min of oxygen } \\
\text { ( } 7.23 \mathrm{Kcal} / \mathrm{min} \text {, using a conversion factor of } 4.82 \text { ) which classified bricklaying as "heavy work". } \\
\text { A rest allowance of } 64.45 \% \text { ( } 38.67 \text { minutes rest for } 60 \text { minutes work duration) was calculated . } \\
\text { It was concluded that there is a need to redesign the work content of the aforementioned } \\
\text { occupation in order to reduce excessive strain on the workers, which in turn will increase } \\
\text { productivity. }\end{array}$ \\
\hline
\end{tabular}

\section{Introduction}

Working in the construction industry has been considered to have ergonomic problem due to the fact that it requires working above the shoulder and below the knee height (Schneider \& Susi, 1994). Similarly, Samuelsson and Lundholm (2006) observed that the ergonomic problem in the construction industry could be as a result of heavy lifting, working on one side, and strenuous work postures. While, Larcher and Sohail (1999) noted that there are huge financial cost and human agonies associated with construction industry. Simonsson and Rwamamara (2007) observed that measuring the significance of work related accidents and personnel turnover in construction company may be difficult. The activities associated with construction industry were highlighted by Snook (1982) as a potential risk area. Despite the various hazards that the construction workers are exposed to, there has been very little attention towards the health and safety of these workers (Koningsveld \& Van Der Molen, 1997).

* Corresponding author. Tel: +234 8051449269

E-mail addresses: ismailasalami@yahoo.com (S. O. Ismaila) 
In developing countries like Nigeria, labour cost is cheap and most work in the construction industries are done manually. In such countries the physical demands of the task often exceed the physical capabilities of the worker (Scott \& Charteris, 2004). In fact, Sluiter and Frings-Dresen (2007) noted that for a type of work to be compatible with the worker and to enhance productivity, the health status, physical capabilities, absence of sickness, absence of accidents and task performance are essential. Physical tests have been used by organizations to assess the capability of workers for physically demanding jobs as in military formations (Blizon, 2002). As a result of this fact, many ways have been adopted in measuring workers' responses to manual tasks in order to appraise the incompatibility, and to evaluate the effectiveness of intervention strategies. In order to match a person's work capacity with the requirements of his/her job, there is a need to know the individual's energy capacity and how much the job demands from this capacity. The energy requirements of a given task are determined by allowing a "standard" person to perform the task and again measure the person's reactions to the task. However, Kroemer et al. (2000) recommended the measurement of reaction of workers since "standard" people are usually not available. The heart rate is commonly used to estimate the energy expenditure or physical strain during sports, work or daily activities (Bot \& Hollander, 2000; McArdle et al., 2001). This indirect method is based on a linear relationship between heart rate (HR) and oxygen uptake $\left(\mathrm{VO}_{2}\right)$ during steady state conditions and gives the opportunity of an easy and relatively inexpensive determination of the $\mathrm{VO}_{2}(\mathrm{Scott} \&$ Christie, 2004; McArdle et al., 2001; Bot et al., 2000; Haskell et al., 1992; Strath et al., 2004).

Stifelman (2007) discussed techniques to measure human energy expenditure in bricklayers. Similarly, Oke et al. (2008) developed a framework for energy expenditure for bricklayer under different postures to provide information on the type of posture to be adopted for bricklaying and estimating the energy required at such postures. However, the methodology provided may only be used in the laboratory setting. Therefore, the study of the work capacity or energy expenditure of bricklayers is still an interesting area of research especially for Nigerian bricklayers. The nonavailability of oxygen measuring equipment and the fact that its use may interfere with the work of the bricklayers allowed for the methodology adopted by Scott and Christie (2004) and others (McArdle et al., 2001; Bot et al., 2000; Haskell et al., 1992; Strath et al., 2004) to determine the energy expenditure, physiological response and aerobic strain of bricklayers including margin of safety on field.

\section{Material and methods}

The field study was conducted at building sites in Ibadan and Eruwa in Oyo state of Nigeria. 89 (Eighty Nine) Bricklayers working on different building sites participated in the study. The heart rates (HR) of each worker were measured with the use of a digital sphygmomanometer (POLYGON YS796). The resting heart rate was measured by asking the subject to sit down quietly for five minutes and then measuring the resultant heart rate. Working heart rate was measured while the bricklayers were working over a one hour period that did not include breaks. Weights of the workers were also recorded with weighing machine (HARSON H89DK) before the start of work. The measurements of the weights were to the nearest $0.1 \mathrm{~kg}$ and the subjects were on the machine with bare foot, light clothing and stayed for between one and two minutes. Moreover, the heights of the workers were measured using a locally fabricated Standiometer. $\mathrm{VO}_{2}$ of each participant was 
determined form the HR values obtained during the experiment using the linear regression model developed by Scott and Christie (2004) as:

$\mathrm{Y}=0.259 \mathrm{X}-6.422$, where $\mathrm{Y}=$ predicted oxygen consumption in $\mathrm{ml} . \mathrm{kg}^{-1} \mathrm{~min}^{-1}, \mathrm{X}=$ measured heart rate in beats $\min ^{-1}$; $\mathrm{VO}_{2 \max }$ was also determined by using Astrand - Astrand nomogram as modified by Tayyari and Smith (2003) as:

For men: $\mathrm{VO}_{2 \max }=\mathrm{AG} .\left(131.5 . \mathrm{VO}_{2}\right) \div(\mathrm{HR}-62)$,

For women: $\mathrm{VO}_{2 \max }=\mathrm{AG} .\left(131.5 \cdot \mathrm{VO}_{2}\right) \div(\mathrm{HR}-72)$,

where $\mathrm{AG}=1.12-0.0073$ age.

The energy expenditure of bricklayers was determined and relationships between weight and $\mathrm{VO}_{2}$; weight and $\mathrm{VO}_{2 \max }$; age and $\mathrm{VO}_{2}$; age and $\mathrm{VO}_{2 \max }$; heart rates and $\mathrm{VO}_{2}$; heart rates and $\mathrm{VO}_{2 \max }$ were established using Paired samples t- test as available in SPSS 16.0 Statistical package.

The RHR which is also an indicator of physical workload that is related to muscular activities as reported by Wu and Wang (2002) was calculated. \% RHR was given as,

$\% \mathrm{RHR}=\frac{H R_{W}-H R_{r}}{H R_{M A X}-H R_{r}}$,

where $\mathrm{HR}_{\mathrm{W}}=$ Average Working $\mathrm{HR}, \mathrm{HR}_{\mathrm{r}}=$ Resting $\mathrm{HR}, \mathrm{HR}_{\mathrm{MAX}}=$ Maximum $\mathrm{HR}$, given as 220-age (Astrand \& Rodahl, 1986). For manual activities rest allowance (RA) should be provided as compensation. The RA was calculated using the following equation adapted from Niebel and Freivalds (2003):

$\mathrm{RA}=\left(\partial \mathrm{HR} / \mathrm{HR}_{\mathrm{W}}\right)^{*} 100$

where RA $=$ Rest Allowance, as percentage that is added to Working Time (WT), and $\partial \mathrm{HR}=$ Working HR- Resting HR.

\section{Results}

The summary of the anthropometric characteristics and working heart rates in terms of percentiles, means and standard deviations are presented in Table 1.

\section{Table 1}

Summary of anthropometric characteristics and working heart rates

\begin{tabular}{|c|c|c|c|c|c|c|c|}
\hline \multicolumn{8}{|c|}{ Percentiles } \\
\hline & $5^{\text {th }}$ & $50^{\text {th }}$ & $95^{\text {th }}$ & Min & Max & Mean & $\mathrm{SD}$ \\
\hline Height (m) & 1.5 & 1.6 & 1.8 & 1.3 & 1.8 & 1.6 & 0.1 \\
\hline Age (Years) & 21 & 32 & 47 & 16 & 60 & 33.7 & 8.4 \\
\hline Weight (Kg) & 51 & 60 & 70 & 45 & 79 & 60.4 & 6.1 \\
\hline $\mathrm{BMI}\left(\mathrm{Kg} / \mathrm{m}^{2}\right)$ & 17.6 & 22.2 & 28.3 & 17 & 33.1 & 22.7 & 3.4 \\
\hline $\mathrm{HR}_{\mathrm{r}}(\mathrm{bpm})$ & 54.8 & 69 & 81.6 & 53 & 92 & 68.6 & 8.3 \\
\hline $\mathrm{HR}_{\mathrm{w}}(\mathrm{bpm})$ & 100 & 119 & 146 & 94 & 157 & 120.8 & 15.7 \\
\hline $\mathrm{VO}_{2}(1 . / \mathrm{min})$ & 1.1 & 1.5 & 2.0 & 0.8 & 2.3 & 1.5 & 0.3 \\
\hline $\mathrm{VO}_{2} \max (1 . / \mathrm{min})$ & 2.0 & 2.3 & 2.7 & 1.9 & 2.8 & 2.3 & 0.2 \\
\hline$\% \mathrm{VO}_{2} \max$ & 34.5 & 50.0 & 73.9 & 24.4 & 91.3 & 52.0 & 14.8 \\
\hline$\%$ RHR & 28.2 & 55.2 & 87.4 & 11.4 & 104.5 & 57.4 & 20.0 \\
\hline
\end{tabular}


The mean height of the bricklayers that were studied was $1.6 \mathrm{~m}$ while their mean age was 33.7 years. The mean body mass index (BMI) which is a measure of obesity and defined as weight in kilograms divided by height in metres squared was $22.7 \mathrm{Kg} / \mathrm{m}^{2}$. The bricklayers expended an average of 1.51 $/ \mathrm{min}$ of oxygen $(7.23 \mathrm{Kcal} / \mathrm{min}$, using a conversion factor of 4.82$)$ whiles the calculated percentage relative heart rate (RHR) was 58.5\% (SD 19.0\%). The mean working heart rate was $120.8 \mathrm{bpm}$ and the resting heart rate was $68.6 \mathrm{bpm}$.

The Paired Samples T-Test conducted showed a positive correlation between age and $\mathrm{VO}_{2}(\mathrm{r}=0.279$, $\mathrm{P}=0.008)$; no correlation between age and $\mathrm{VO}_{2 \max }(\mathrm{r}=0.095, \mathrm{P}=0.377)$; no correlation between age and \%RHR $(\mathrm{r}=-0.030, \mathrm{P}=0.778)$. Similarly, there was no correlation between age and working heart rate $(\mathrm{r}=0.068, \mathrm{P}=0.527)$. Weight of the subjects are correlated positively with $\mathrm{VO}_{2}(\mathrm{r}=0.698$, $\mathrm{P}=0.000)$, working heart rate $(\mathrm{r}=0.326, \mathrm{P}=0.002)$ and $\% \mathrm{HRH}(\mathrm{r}=0.266, \mathrm{P}=0.012)$ but had no correlation with $\mathrm{VO}_{2 \max }(\mathrm{r}=-0.010, \mathrm{P}=0.925)$.

BMI had a positive correlation with \% RHR $(\mathrm{r}=0.220, \mathrm{P}=0.038)$ and $\mathrm{VO}_{2}(\mathrm{r}=0.330, \mathrm{P}=0.002)$ but no correlation with both working heart rate $(\mathrm{r}=0.194, \mathrm{P}=0.069)$ and $\mathrm{VO}_{2 \max }(\mathrm{r}=0.090, \mathrm{P}=0.400)$. The models which best describe the relationship between the variables, which have correlation were determined using the SPSS 16.0 Statistical Package. Table 2 shows the relationship between $\mathrm{VO}_{2}$ and age. From the Table, the curve that best describes the relationship is S-Equation with the highest $\mathrm{R}$ Square of 0.108 (Table 2), which gives the relationship as:

$\mathrm{Y}=e^{\left(0.674-\frac{9.046}{\text { Age }}\right)}$, where $\mathrm{Y}=\mathrm{VO}_{2}$

Table 2

Relationship between $\mathrm{VO}_{2}$ and Age (Dependent Variable: $\mathrm{VO}_{2}$, The independent variable is Age)

\begin{tabular}{llllllllll}
\hline & \multicolumn{3}{l}{ Model Summary } & \multicolumn{5}{c}{ Parameter Estimates } \\
\cline { 2 - 10 } Equation & \multicolumn{2}{l}{ R Square $\mathrm{F}$} & $\mathrm{df1}$ & $\mathrm{df2}$ & Sig. & Constant & $\mathrm{b} 1$ & $\mathrm{~B} 2$ & $\mathrm{~b} 3$ \\
\hline Linear & .078 & 7.341 & 1 & 87 & .008 & 1.144 & .011 & & \\
Logarithmic & .093 & 8.871 & 1 & 87 & .004 & .091 & .407 & & \\
Inverse & .101 & 9.786 & 1 & 87 & .002 & 1.921 & -13.041 & & \\
Quadratic & .104 & 4.968 & 2 & 86 & .009 & .538 & .045 & .000 & \\
Cubic & .105 & 3.313 & 3 & 85 & .024 & .894 & .014 & .000 & $-7.716 \mathrm{E}-6$ \\
Compound & .080 & 7.542 & 1 & 87 & .007 & 1.150 & 1.007 & & \\
Power & .096 & 9.246 & 1 & 87 & .003 & .558 & .279 & & \\
S & .108 & 10.493 & 1 & 87 & .002 & .674 & -9.046 & & \\
Growth & .080 & 7.542 & 1 & 87 & .007 & .140 & .007 & & \\
Exponential & .080 & 7.542 & 1 & 87 & .007 & 1.150 & .007 & & \\
Logistic & .080 & 7.542 & 1 & 87 & .007 & .870 & .993 & & \\
\hline
\end{tabular}

The model that best predicts the $\mathrm{VO}_{2}$ given the weight of the bricklayers is the power equation with the highest $\mathrm{R}$ Square of 0.515 (Table 3 ) and is given as:

$\mathrm{Y}=0.003 *$ Weight $* 1.535$ 
Table 3

Relationship between $\mathrm{VO}_{2}$ and Weight (Dependent Variable: $\mathrm{VO}_{2}$, The independent variable is Weight)

\begin{tabular}{|c|c|c|c|c|c|c|c|c|c|}
\hline \multirow[b]{2}{*}{ Equation } & \multicolumn{5}{|c|}{ Model Summary } & \multicolumn{4}{|c|}{ Parameter Estimates } \\
\hline & R Square & $\mathrm{F}$ & Df1 & $\mathrm{df} 2$ & Sig. & Constant & b1 & $\mathrm{B} 2$ & b3 \\
\hline Linear & .488 & 82.847 & 1 & 87 & .000 & -.750 & .037 & & \\
\hline Logarithmic & .488 & 82.932 & 1 & 87 & .000 & -7.593 & 2.223 & & \\
\hline Inverse & .480 & 80.270 & 1 & 87 & .000 & 3.658 & -128.383 & & \\
\hline Quadratic & .490 & 41.360 & 2 & 86 & .000 & -1.753 & .071 & .000 & \\
\hline Cubic & .491 & 41.549 & 2 & 86 & .000 & -1.561 & .058 & .000 & $-1.846 \mathrm{E}-6$ \\
\hline Compound & .509 & 90.075 & 1 & 87 & .000 & .312 & 1.026 & & \\
\hline Power & .515 & 92.390 & 1 & 87 & .000 & .003 & 1.535 & & \\
\hline $\mathrm{S}$ & .513 & 91.576 & 1 & 87 & .000 & 1.882 & -89.230 & & \\
\hline Growth & .509 & 90.075 & 1 & 87 & .000 & -1.163 & .026 & & \\
\hline Exponential & .509 & 90.075 & 1 & 87 & .000 & .312 & .026 & & \\
\hline Logistic & .509 & 90.075 & 1 & 87 & .000 & 3.200 & .975 & & \\
\hline
\end{tabular}

The \% RHR can best be predicted using any of the following equations as they have the same R Square of 0.243 as shown in Table 4:

1. $\mathrm{Y}=12.210 * 1.024 *$ Weight

2. $\mathrm{Y}=e^{(2.502+0.023 * \text { Weight })}$

3. $\mathrm{Y}=12.210 *\left(e^{(0.023 * \text { Weight })}\right)$

Table 4

Relationship between \% RHR and Weight (Dependent Variable: \%RHR, The independent variable is Weight)

\begin{tabular}{|c|c|c|c|c|c|c|c|c|c|}
\hline \multirow[b]{2}{*}{ Equation } & \multicolumn{5}{|c|}{ Model Summary } & \multicolumn{4}{|c|}{ Parameter Estimates } \\
\hline & R Square & $\mathrm{F}$ & Df1 & df2 & Sig. & Constant & b1 & $\mathrm{B} 2$ & b3 \\
\hline Linear & .221 & 24.717 & 1 & 87 & .000 & -17.109 & 1.145 & & \\
\hline Logarithmic & .215 & 23.869 & 1 & 87 & .000 & -222.578 & 67.048 & & \\
\hline Inverse & .205 & 22.502 & 1 & 87 & .000 & 115.876 & -3815.665 & & \\
\hline Quadratic & .223 & 12.351 & 2 & 86 & .000 & 22.472 & -.182 & .011 & \\
\hline Cubic & .223 & 12.359 & 2 & 86 & .000 & 13.256 & .000 & .013 & $-3.350 \mathrm{E}-5$ \\
\hline Compound & .243 & 28.000 & 1 & 87 & .000 & 12.210 & 1.024 & & \\
\hline Power & .238 & 27.211 & 1 & 87 & .000 & .183 & 1.370 & & \\
\hline S & .229 & 25.807 & 1 & 87 & .000 & 5.220 & -78.214 & & \\
\hline Growth & .243 & 28.000 & 1 & 87 & .000 & 2.502 & .023 & & \\
\hline Exponential & .243 & 28.000 & 1 & 87 & .000 & 12.210 & .023 & & \\
\hline Logistic & .243 & 28.000 & 1 & 87 & .000 & .082 & .977 & & \\
\hline
\end{tabular}

Table 5 shows the relationships to predict the working heart rate using the weight of the bricklayers as follows:

$\mathrm{Y}=9.935+2.352 *$ Weight 


\section{Table 5}

Relationship between working heart rate and weight (Dependent Variable: $H R_{W}$, The independent variable is Weight)

\begin{tabular}{|c|c|c|c|c|c|c|c|c|}
\hline \multirow{3}{*}{$\frac{\text { Equation }}{\text { Linear }}$} & \multirow{3}{*}{$\frac{\text { R Square }}{.106}$} & \multirow{2}{*}{$\mathrm{F}$} & \multicolumn{2}{|c|}{ Model Summary } & \multicolumn{4}{|c|}{ Parameter Estimates } \\
\hline & & & df2 & Sig. & Constant & B1 & $\mathrm{b} 2$ & b3 \\
\hline & & 10.3541 & 87 & .002 & 70.167 & .839 & & \\
\hline Logarithmic & .109 & 10.6231 & 87 & .002 & -85.539 & 50.389 & & \\
\hline Inverse & .109 & 10.6181 & 87 & .002 & 169.941 & -2934.504 & & \\
\hline Quadratic & .113 & $5.482 \quad 2$ & 86 & .006 & -8.755 & 3.484 & -.022 & \\
\hline Cubic & .115 & $5.592 \quad 2$ & 86 & .005 & 9.935 & 2.352 & .000 & .000 \\
\hline Compound & .111 & 10.8241 & 87 & .001 & 78.367 & 1.007 & & \\
\hline Power & .113 & 11.1111 & 87 & .001 & 21.237 & .423 & & \\
\hline S & .113 & 11.1091 & 87 & .001 & 5.198 & -24.610 & & \\
\hline Growth & .111 & 10.8241 & 87 & .001 & 4.361 & .007 & & \\
\hline Exponential & .111 & 10.8241 & 87 & .001 & 78.367 & .007 & & \\
\hline Logistic & .111 & 10.8241 & 87 & .001 & .013 & .993 & & \\
\hline
\end{tabular}

As shown in Table 6, the $\mathrm{VO}_{2}$ can be predicted fairly given BMI, using the following equation:

$$
Y=-0.515+0.117 * B M I-5.079 * 10^{-5} * B M I^{3}
$$

\section{Table 6}

Relationship between $\mathrm{VO}_{2}$ and $\mathrm{BMI}$ (Dependent Variable: $\mathrm{VO}_{2}$, the independent variable: $\mathrm{BMI}$ )

\begin{tabular}{|c|c|c|c|c|c|c|c|c|c|}
\hline \multirow[b]{2}{*}{ Equation } & \multicolumn{5}{|c|}{ Model Summary } & \multicolumn{4}{|c|}{ Parameter Estimates } \\
\hline & R Square & $\mathrm{F}$ & df1 & df2 & Sig. & Constant & B1 & $\mathrm{B} 2$ & b3 \\
\hline Linear & .109 & 10.655 & 1 & 87 & .002 & .800 & .031 & & \\
\hline Logarithmic & .117 & 11.494 & 1 & 87 & .001 & -.804 & .743 & & \\
\hline Inverse & .121 & 11.979 & 1 & 87 & .001 & 2.273 & -16.959 & & \\
\hline Quadratic & .135 & 6.714 & 2 & 86 & .002 & -1.086 & .195 & -.003 & \\
\hline Cubic & .138 & 6.904 & 2 & 86 & .002 & -.515 & .117 & .000 & $-5.079 \mathrm{E}-5$ \\
\hline Compound & .113 & 11.046 & 1 & 87 & .001 & .908 & 1.022 & & \\
\hline Power & .121 & 11.928 & 1 & 87 & .001 & .303 & .508 & & \\
\hline $\mathrm{S}$ & .125 & 12.457 & 1 & 87 & .001 & .911 & -11.600 & & \\
\hline Growth & .113 & 11.046 & 1 & 87 & .001 & -.097 & .021 & & \\
\hline Exponential & .113 & 11.046 & 1 & 87 & .001 & .908 & .021 & & \\
\hline Logistic & .113 & 11.046 & 1 & 87 & .001 & 1.101 & .979 & & \\
\hline
\end{tabular}

There a weak association between the \% RHR and BMI and as such the relationship may not be predicted fairly as shown in Table 7 . The Rest Allowance (RA) was calculated to be $64.45 \%$

\section{Discussion}

The bricklayers in this study expended an average of $1.51 \mathrm{~min}^{-1}$ of oxygen and mean heart rate of $120.8 \mathrm{bpm}$, which classified their work as "heavy work" using the classification of Kroemer et al. (2000). Kroemer et al. (2000) defined the heaviness of work as:

Light work: up to $10 \mathrm{KJ}(2.5 \mathrm{Kcal})-90$ beats per minute 
Medium work: about $20 \mathrm{KJ}(5 \mathrm{Kcal})-100$ beats per minute

Heavy work: about $30 \mathrm{KJ}(7.5 \mathrm{kcal})-120$ beats per minute

Very heavy work: about 40KJ (10Kcal) - 140 beats per minute.

Extremely heavy work: $50 \mathrm{KJ}(12.5 \mathrm{Kcal})-160$ beats per minute.

Table 7

Relationship between \%RHR and BMI (Dependent Variable: \%RHR, The independent variable is BMI)

\begin{tabular}{|c|c|c|c|c|c|c|c|c|c|}
\hline \multirow[b]{2}{*}{ Equation } & \multicolumn{5}{|c|}{ Model Summary } & \multicolumn{4}{|c|}{ Parameter Estimates } \\
\hline & R Square & $\mathrm{F}$ & df1 & df 2 & Sig. & Constant & b1 & $\mathrm{B} 2$ & b3 \\
\hline Linear & .048 & 4.420 & 1 & 87 & .038 & 30.556 & .945 & & \\
\hline Logarithmic & .052 & 4.763 & 1 & 87 & .032 & -18.050 & 22.519 & & \\
\hline Inverse & .053 & 4.906 & 1 & 87 & .029 & 75.052 & -511.546 & & \\
\hline Quadratic & .064 & 2.958 & 2 & 86 & .057 & -36.756 & 6.799 & -.124 & \\
\hline Cubic & .068 & 3.134 & 2 & 86 & .049 & -18.328 & 4.140 & .000 & -.002 \\
\hline Compound & .056 & 5.151 & 1 & 87 & .026 & 31.903 & 1.020 & & \\
\hline Power & .060 & 5.550 & 1 & 87 & .021 & 11.563 & .470 & & \\
\hline $\mathrm{S}$ & .062 & 5.728 & 1 & 87 & .019 & 4.392 & -10.691 & & \\
\hline Growth & .056 & 5.151 & 1 & 87 & .026 & 3.463 & .020 & & \\
\hline Exponential & .056 & 5.151 & 1 & 87 & .026 & 31.903 & .020 & & \\
\hline Logistic & .056 & 5.151 & 1 & 87 & .026 & .031 & .980 & & \\
\hline
\end{tabular}

The bricklayers work is also 'heavy work' using the classification of Astrand and Rodahl (1986) which gave the following classification of severity of work load for prolonged physical work in terms of mean heart rate as:

up to 90 bpm: 'light work';

90 to 110 bpm: 'moderate work';

110 to 130 bpm: 'heavy work';

130 to 150 bpm: 'very heavy work'

150 to 170 bpm: 'extremely heavy work'.

The mean heart rate $(120.8 \mathrm{bpm})$ needed to do bricklaying work in the present study was above the recommended limit of $110 \mathrm{bpm}$ for an 8-hour work shift (Sanders \& McCormick, 1993; Saha et al., 1979). Maritz et al. (1961) had suggested an average working HR of $105 \mathrm{bpm}$ for standard 8-hr industrial job with a range of $95-115 \mathrm{bpm}$.

The results of the present study differs from the work of Astrand (1967) which found a mean heart rate for 10 bricklayers as $97.9 \mathrm{bpm}$ (SD $9.5 \mathrm{bpm}$ ). The difference in the two studies may as a result of the number of subjects involved as the present study used 89 bricklayers.

The mean $\% \mathrm{VO}_{2 \mathrm{Max}}$ of $52 \%$ was more than the recommended $33 \%$ as recommended by the NIOSH Committee. The \% RHR of $57.4 \%$ obtained from the study was higher than $30 \%$ recommended by Shimaoka et al. (1998) and 24.5\% recommended by Wu and Wang (2002). The significance of these 
findings is that tasks performed can cause high cardiovascular load for an 8-h workday and subject the workers to fatigue and higher muscular strains. The resultant effect of this is associated muscular pain. Knight (1984) gave the following classification regarding whether subjects are underweight, normal, overweight or obese:

$<20$ Underweight;

20-25 Normal;

25-30 Overweight;

$>30$ Obese.

The mean value of $22.7 \mathrm{Kg} / \mathrm{m}^{2}$ obtained was midway in the normal range, suggesting that bricklayers may be towards the heavy-for-height end of the population with a proportion being overweight. The maximum BMI obtained was $33.1 \mathrm{Kg} / \mathrm{m}^{2}$ and the minimum $17.0 \mathrm{Kg} / \mathrm{m}^{2}$. Using the adapted Niebel and Freivalds (2003) equation, the rest time should be $64.45 \%$ while the work time should be $35.55 \%$ which means a rest time of 38.67 minutes within 60 minutes of work. This is necessary to compensate for the fatigue due to physical strain. The required rest period was very high as compared to the actual rest time in the field as the bricklayers only rest while eating, drinking or waiting for materials and these are not done every hour. Therefore, cumulative muscular fatigue would set in and may lead to high risk of occupational health hazard conditions while working with a resultant pain after the day's job.

\section{Conclusion}

From the study on bricklayers, it was observed that physical work capacity depends on anthropometric characteristics of the bricklayers. With ageing, physical work capacity rapidly diminished even with increase in body weight. The work contents of the bricklayers are usually above the recommended value and could lead to physiological strain on the workers which may be overcome by redesigning the working system.

Thus, redesign of workplace and work method is urgently required to reduce the work stress factor. It is recommended that the field working conditions in Nigeria are very risky and accident-prone. The occupational health status of the workers associated with this highly demanding industry needs to be considered to reduce accidents and injuries on site. Lifting and motorized positioning devices should be provided in order to reduce the stress and energy expenditure involved in carrying loads. Manual workers should be tested and evaluated for their fitness for a particular task, and their working time should be optimized without discomfort, to harness maximum efficiency of the worker for the designated operation, which will increase the net output.

\section{References}

Astrand, I. (1967). Degree of strain during building work as related to individual aerobic work capacity. Ergonomics, 10, 293-303.

Astrand, P.O. and Rodahl, K. (1986). Textbook of Work Physiology: Physiological Bases of Exercise. New York: McGraw-Hill Book Company, $3^{\text {rd }}$ Edition. 
Blizon, J.L., Scarpello, E.G., Blizon, E., \& Allsop, A.J. (2002). Generic task related occupational requirements of Royal Navy personnel. Occupational Medicine, 52, 503-510.

Bot, S.D.M., \& Hollander, A.P. (2000). The relationship between heart rate and oxygen uptake during non-steady state exercise. Ergonomics, 43(10), 1578- 1592.

Haskell, W.L., Yee, M.C., Evans, A., \& Irby, P.J. (1992). Simultaneous measurement of heart rate and body motion to quantify physical activity. Medicine and Science in Sports and Exercise, 25(1), 109-115.

Knight, I. (1984). The heights and weights of adults in Great Britain. (London: HMSO)

Kroemer, K., Kroemer, H., \& Kroemer-Elbert, K. (2000). Ergonomics how to design for easy and efficiency. $2^{\text {nd }}$ Edition. Prentice Hall, New Jersey.

Larcher, P., \& Sohail, M. (1999). WELL Study; Review of Safety in Construction and Operation for the WS\&S Sector: Part I. Task No: 166; London School of Hygiene \& Tropical Medicine and WEDC, Loughborough University, UK.

McArdle, W.D., Katch, F.I., \& Katch, V.L. (2001). Exercise physiology, Energy, Nutrition, and Human performance, 5th edu, $165-172$. Williams and Wilkins, Baltimore.

Niebel, B.W., \& Freivalds, A. (2003). Methods, standards and work design, $11^{\text {th }}$ Edition. McGrawHill, Boston, MA.

Oke S.A., Oshiafi I.K., Akanbi O.G., Kolawole A., \& Oyawale F.A. (2008). Modelling energy expenditure of a brick layer at various postures, Ergonomics SA, 20 (2), 34-44.

Simonsson, P., \& Rwamamara, R. (2007). Consequence of Industrialized Construction Methods on the Working Environment, Proceedings IGLC-15, July 2007, Michigan, USA

Saha, P.N., Datta, S.R., Banerjee, P.K., \& Narayane, G.G. (1979). An acceptable workload for Indian workers. Ergonomics 22, 1059-1071.

Samuelsson, B., \& Lundholm, L. (2006). Arbetsskador inom byggindustrin 2005. Byggoch anläggning. Private sector. BCA 2006:2.

Sanders, M.S., \& McCormick, E.J. (1993). Human Factors in Engineering and Design. Seventh Edition. New York: McGraw- Hill.

Schneider, S., \& Susi, P. (1994). Ergonomics and Construction: A review of potential hazards in new construction. American Industrial Hygiene Association Journal, 55 (7), 635-649.

Scott, P. A., \& Christie C.J. (2004). A Preliminary Field Assessment of the Energy Expenditure of Forestry Workers in South Africa. Human Factors and Ergonomics Society Annual Meeting Proceedings, Industrial Ergonomics, 5, 1412-1416.

Scott, P.A., \& Christie, C.J. (2004). An indirect method to assess the energy expenditure of manual labourers in situ. South Africa Journal of Science, 100, $694-698$.

Shimaoka, M., Hiruta, S., Ono, Y., Nonaka, H., Hjelm, E.W., \& Hagberg, M. (1998). A comparative study of physical work load in Japanese and Swedish nursery school teachers. European Journal of Applied Physiology, 77, 10-18.

Sluiter, J., \& Frings-Dresen (2007). What do we know about ageing at work? Evidence based fitness for duty and health in fire fighters. Ergonomics, 50(11), 1897-1913.

Snook, S.H. (1982). Low back pain in industry, symposium on idiopathic low back pain. In: White, A.A., Gordon, S.L. (Eds.), Mosby Company. St. Louis, MO, 23-38.

Strath S.J., Bassett D. R., Thompson D. L., \& Swart A. M. (2002). Validity of simultaneous heart rate- motion sensor technique for measuring energy expenditure. Medicine and Science in Sports and Exercise, 34(5), 888-894. 
272

Tayyari, F., \& Smith, J. (2003). Occupational Ergonomics principles and applications. Kluwer Academic publishers: Massachusetts.

Wu, H.C., \& Wang, M.J. (2002). Relationship between maximum acceptable work time and physical workload. Ergonomics, 45, 280-289. 